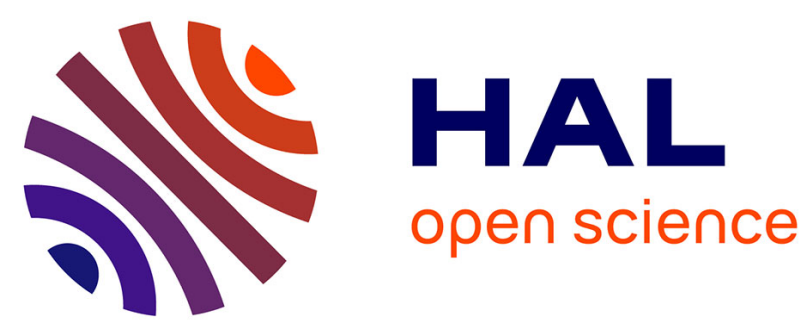

\title{
Farmer flexibility concerning future rotation planning is affected by the framing of climate predictions
}

\author{
Miranda S. Bane, Michael J. O. Pocock, Caroline Gibert, Matthieu Forster,
} Geoffroy Oudoire, Stephane A. P. Derocles, David Bohan

\section{- To cite this version:}

Miranda S. Bane, Michael J. O. Pocock, Caroline Gibert, Matthieu Forster, Geoffroy Oudoire, et al.. Farmer flexibility concerning future rotation planning is affected by the framing of climate predictions. Climate Risk Management, 2021, 34, 10.1016/j.crm.2021.100356 . hal-03421454

\section{HAL Id: hal-03421454 https://hal.science/hal-03421454}

Submitted on 9 Nov 2021

HAL is a multi-disciplinary open access archive for the deposit and dissemination of scientific research documents, whether they are published or not. The documents may come from teaching and research institutions in France or abroad, or from public or private research centers.
L'archive ouverte pluridisciplinaire HAL, est destinée au dépôt et à la diffusion de documents scientifiques de niveau recherche, publiés ou non, émanant des établissements d'enseignement et de recherche français ou étrangers, des laboratoires publics ou privés.

\section{(1) (1) $\$$}

Distributed under a Creative Commons Attribution - NonCommercial - NoDerivatives| 4.0 


\title{
Farmer flexibility concerning future rotation planning is affected by the framing of climate predictions
}

\author{
Miranda S. Bane ${ }^{\mathrm{a}, \mathrm{b}, *}$, Michael J.O. Pocock ${ }^{\mathrm{a}}$, Caroline Gibert ${ }^{\mathrm{c}}$, Matthieu Forster ${ }^{\mathrm{d}, \mathrm{e}}$, \\ Geoffroy Oudoire $^{\mathrm{d}, \mathrm{f}}$, Stéphane A.P. Derocles ${ }^{\mathrm{d}, \mathrm{g}}$, David A. Bohan ${ }^{\mathrm{d}}$ \\ ${ }^{\text {a }}$ UK Centre for Ecology \& Hydrology, Wallingford, Oxfordshire OX10 8BB, UK \\ ${ }^{\mathrm{b}}$ School of Biological Sciences, University of Bristol, Bristol BS8 1UG, UK \\ ${ }^{\mathrm{c}}$ Solagro, 75 voie du TOEC CS 27608, 31076 Toulouse Cedex 3, France \\ d Agroécologie, AgroSup Dijon, INRAe Univ. Bourgogne, Univ. Bourgogne-Franche-Comté, 21000 Dijon, France \\ e UniLaSalle, 60026 Beauvais, France \\ ${ }^{\mathrm{f}}$ Arvalis, Service Agronomie Economie Environnement Station Expérimentale Boigneville, 91270 Boigneville, France \\ ${ }^{\mathrm{g}}$ IGEPP, Agrocampus Ouest, INRAe, Université de Rennes 1, Université Bretagne-Loire, 35000 Rennes, France
}

\section{A R T I C L E I N F O}

\section{Keywords:}

Agronomy

Arable farming

Climate change

Outlook

Planning

Rotations

\begin{abstract}
A B S T R A C T
Arable crops are typically grown in annual rotations. Diverse rotations can deliver ecosystem services, provide economic resilience, and support adaptation to climate change. Our aim was to assess farmers' attitudes to planning and diversifying crop rotations, focusing on their responses in the face of contrasting climate viewpoints.

We interviewed 75 farmers from four regions along a latitudinal gradient from the south of the UK to the south of France. We used a semi-structured questionnaire with face-to-face interviews and asked farmers to respond to two narrative viewpoints of climate change impacts: one viewpoint focused on opportunities, the other on constraints.

We found in all four regions that farmers' use rotations, and the crops within rotations, to achieve their main objectives of financial stability and improved soil health. Most farmers (79-100\% depending on region) said they had experienced climate change, and many (54-83\%) had already implemented changes in their farming practices. We did not find a difference in these results based on latitude. However, farmers' self-reported outlook was mostly optimistic in southern UK and become progressively more pessimistic further south. When presented with a viewpoint of climate change impacts focusing on opportunities, more farmers were likely to diversify and lengthen rotations, and fewer were likely to shorten them, compared to a viewpoint presenting constraints from these impacts.

Crucially, here we show that the presentation of climate change affects the ways in which farmers predict how they will respond to climate change. Diversified rotations align with multiple other economic and environmental benefits. Therefore, it is essential to consider the way in which climate change impacts are communicated, and the effect this has farmers' behavior, when designing measures to support environmentally sustainable adaptation to climate change.
\end{abstract}

\footnotetext{
* Corresponding author at: School of Biological Sciences, University of Bristol, Bristol BS8 1UG, UK.

E-mail address: miranda.bane@bristol.ac.uk (M.S. Bane).
} 


\section{Introduction}

Climate change can have significant impacts on agriculture via more extreme and more frequent weather events (e.g. droughts, floods, storms), average temperature change and by facilitating increases in diseases and pests (Olesen and Bindi, 2002). Farming practices have been shown to contribute to climate change (IPCC, 2018) and exacerbate climate change impacts such as loss of biodiversity (Geiger et al., 2010), the breakdown of ecosystem services (Mulder et al., 2017) and soil and water degradation (Ball et al., 2005). Current farming practices will need to adapt to climate change (IPCC, 2018): changing farming practices could help to reduce farming's contribution to climate change (Gan et al., 2014) and increased adaptions to climate change could positively support restoration of biodiversity and ecosystem functioning (Degani et al., 2019).

Agricultural climate change research tends to focus on academic scenarios of climate change, i.e. numerical outputs from probabilistic climate models, to investigate how this will impact yield, growing season, pests and diseases. There have already been significant declines in the yield of some major crops and livestock productivity due to increased average temperature, variability in temperature and precipitation, and extreme weather events in Europe (Ray et al., 2019; Vogel et al., 2019). Climate change will also cause a northward shift of agro-climate zones in the northern hemisphere, so farmers will change crops or varieties of crops to those that better suit shifted sowing and harvesting times (Ceglar et al., 2019). Farmers will have to adapt to climate change alongside other drivers and pressures; though farming systems have always adapted to changing circumstances (Schiere et al., 2012). Indeed, climate change could be an important and powerful driver for the necessary shift towards a more sustainable agriculture.

Crop rotations are defined as sets of crops that are grown in agronomically-determined sequences (Therond et al., 2017) and are a key component of arable farming practice. Rotations have been used to benefit crop productivity by, for example, reducing the impact of weeds (Weisberger et al., 2019), pests (Vasileiadis et al., 2011), diseases (Pankhurst and Lynch, 2005), and improving soil fertility (Bullock, 1992). Rotations can also be used to mitigate climate effects and reduce environmental damage whilst improving productivity and economic stability (Behnke et al., 2018; Sindelar et al., 2016; Teixeira et al., 2018). Crop and rotational diversification could therefore contribute to the sustainability of future agriculture in terms of ecosystem services, biodiversity conservation and resilience to climate change (Storkey et al., 2019).

Across Europe, crop rotations are subject to regulations that require the diversification of crops through measures to reform the Common Agricultural Policy (European Environment Agency, 2019) but much of the decision-making is left to the individual farmer. Farmers' attitudes towards climate change and their ability and desire to adapt their practices are crucial. Where arable farmers are flexible and optimistic, we expect that this will foster greater ability and success in adapting to and mitigating climate change.

Local climate impacts are important influences on farmer decision-making. Haden et al. (2012) found that local impacts lead to adaptation (i.e. changing actions in response to the effects of climate change) which differ from mitigation (i.e. changing actions to reduce climate change) based on global issues. It has been suggested that farmers are more likely to adapt to climate change than to mitigate (Arbuckle et al, 2015). Studies have shown that many factors feed into the need and ability to adapt, especially around beliefs of the effects of climate change and its associated risks, farmers' socio/cultural/economic background, and their access to information (Arbuckle et al 2015, Nguyen et al., 2016). Some modelling of crop rotations has successfully incorporated climate predictions and farmer behavior (Castellazzi et al., 2008). However, research on climate change mitigation and adaptation often does not consider the importance of farmers' behavior and values (but see for example, Feola and Binder (2010) and Wolf (2011)) and "existing research too often relies on theoretical models that do not capture the complexity of farmer behavior" (Feola et al., 2015). As highlighted by Dury et al., (2012), incorporating farmers' decision making process in future research would be a "promising improvement" for adaptation. Effective communication between farmers and researchers is key to better inform climate research and co-development of future farming practices because miscommunication between experts and farmers can lead to maladaptation Eitzinger et al. (2018) whilst good communication strengthens farmers ability to adapt (Mitter et al, 2019).

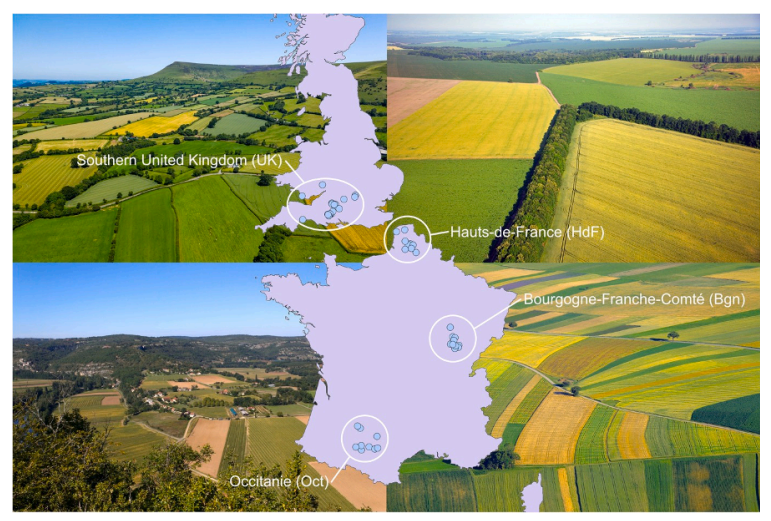

Fig. 1. Locations of the farms in the Southern United Kingdom (UK), and the Hauts-de-France (HdF), Bourgogne-Franche-Comté (Bgn) and Occitanie (Oct) in France accompanied by photos of typical arable fields in each region. These sampling locations form a roughly North to South, latitudinal transect across Western Europe and we expect that the probability of having experienced climate change increases towards the south of the transect. The abbreviations used here are used throughout the rest of the figures in this paper to refer to the regions. 
The overarching aim of this work is to better understand farmer optimism, behavior and choice, in order to improve communication between farmers, researchers, and policy makers. This will positively influence the adaptation of agricultural and rotational practices in response to climate change. In this study, we assessed which factors contribute to rotational decision-making by farmers in the context of climate change and we tested how the communication of climate projections influences farmers' responses. We related this to the flexibility of farmers (their ability/willingness to change their crop and rotation plan in order to adapt to a situation) and the optimism of their outlook for the future. Our work used face-to-face interviews (following Young et al., 2018), based on a semistructured questionnaire that was co-developed with a test group of farmers, to gain information from farmers in four regions along a north-south latitudinal gradient (Ceglar et al., 2019) running from southern United Kingdom (UK) to the south of France (Fig. 1).

Specifically, we first sought to understand farmer-approaches to arable farming in terms of rotations or individual crops, to assess: (i) whether they use rotations to achieve particular objectives; (ii) whether their planning of crops and/or rotations is driven by objectives or constraints; and (iii) the extent and drivers of flexibility in their crops/rotations. Secondly, we sought to understand how farmers are responding to climate change by discovering: (iv) whether they felt they have already been impacted by climate change; (v) how they would adapt their rotations in response to a positive and negative viewpoint of future climate change and (vi) if they felt optimistic or pessimistic about future changes in agriculture, particularly in the context of climate change.

We hypothesized that rotations would be used by farmers to plan their cropping, rather than planning based on individual crops, even though the majority of studies of climate change and arable crops only consider crops individually (Leng and Huang, 2017; Lesk et al., 2016; Sloat et al., 2020). We also expected that planning and flexibility would be driven by both objectives and constraints. We expected that the farmers along the latitudinal gradient to have different experiences of climate change and therefore different responses to climate change. However, we anticipated that despite the application of the Common Agricultural Policy in all nations and regions (prior to the U.K. leaving the EU), there would have been different local regulations, traditions, cultures, and geographical features that could have influenced farming practices.

\section{Materials and methods}

\subsection{Development and design of the semi-structured questionnaire}

The data presented in this study were collected via face-to-face interviews with farmers, using a questionnaire. The questionnaire was co-designed with eight farmers in the Bourgogne-Franche-Comté and Occitanie regions of France. We constructed an initial draft of the questionnaire that was then iteratively improved via individual interviews with farmers. It was open and exploratory in format to capture the diversity of farmers' opinions whilst avoiding any presumptions about what is important to them. The co-design suggested that several questions should be posed twice, once using a structured, multiple choice style answer, and then again allowing open discussion. This approach would allow us to cross-check the responses and to confirm the success of the co-construction process (Feola et al., 2015). Several of the questions provoked a considerable amount of discussion, which could be entirely directed by the farmer, or semi-directed by the interviewer to elucidate the key messages, where required. Open questions and discussion can cause analysis issues but when used strategically they generate greater depth and breadth of qualitative understanding $(\mathrm{O}$ ' $\mathrm{Cathain}$ and Thomas, 2004). These discussions provided the context to the questions that we present here to understand how farmers consider crop rotations and might be sensitive to modifying them with future climate change.

\section{Table 1}

The presentation of a single climate scenario from a positive viewpoint and a negative viewpoint. These contrasting outlooks were presented to farmers as two contrasting projections.

\begin{tabular}{|c|c|c|}
\hline & \multicolumn{2}{|l|}{ Viewpoint of climate change } \\
\hline & Positive viewpoint & Negative viewpoint \\
\hline Summary & $\begin{array}{l}\text { A positive viewpoint based on gaining opportunities from } \\
\text { predicted climate change, e.g. increased yield, decrease in frosts, } \\
\text { new crop opportunities }\end{array}$ & $\begin{array}{l}\text { A negative viewpoint based on reduced opportunities from } \\
\text { predicted climate change, e.g. Extreme weather events, Different } \\
\text { rain patterns, Increased pests and diseases }\end{array}$ \\
\hline $\begin{array}{l}\text { Description presented } \\
\text { to French } \\
\text { Farmers }\end{array}$ & $\begin{array}{l}\text { "Le changement climatique est ici modéré et a un impact plutôt } \\
\text { positif sur les rendements de la plupart des cultures. Il y a une } \\
\text { diminution de la fréquence des gelées automnales grâce à une } \\
\text { sensible augmentation des températures. De plus, le semis au } \\
\text { printemps se déroule plus tôt. } \\
\text { Enfin, le changement climatique permet l'adoption et l'intégration } \\
\text { de nouvelles cultures provenant de zones historiquement plus } \\
\text { chaudes." }\end{array}$ & $\begin{array}{l}\text { "Le changement climatique a un impact négatif sur la plupart des } \\
\text { cultures, notamment à cause de catastrophes naturelles plus } \\
\text { fréquentes et plus violentes (sécheresses, vagues de chaleur, } \\
\text { averses de grêle, tempêtes, inondations). La pluie est plus } \\
\text { concentrée en hiver, ce qui implique un surplus d'eau en hiver et } \\
\text { un déficit en été. Le changement climatique induit une plus forte } \\
\text { pression des nuisibles (adventices, champignons, insectes, } \\
\text { maladies) et des maladies et invasions plus fréquentes et intenses." }\end{array}$ \\
\hline $\begin{array}{l}\text { Description presented } \\
\text { to English } \\
\text { farmers }\end{array}$ & $\begin{array}{l}\text { "Climate change is moderate and has a slightly positive impact on } \\
\text { the yield of most crops. There is a decrease in the frequency of early } \\
\text { frosts because of the slight increase in temperature. In addition, } \\
\text { sowing in spring is earlier. Finally, climate change allows the } \\
\text { adoption and integration of new crops from warmer latitudes." }\end{array}$ & $\begin{array}{l}\text { "Climate change has a negative impact on most crops, because of } \\
\text { extreme weather events that are more frequent and more intense } \\
\text { (e.g. droughts, heat waves, hailstorms, storms, floods). The rain is } \\
\text { more concentrated in winter, inducing a surplus of water in winter } \\
\text { and a deficit in summer. Climate change induces a higher pest } \\
\text { pressure (e.g. weeds, fungi, insects, diseases) and more frequent } \\
\text { and intense diseases and/or invasions." }\end{array}$ \\
\hline
\end{tabular}


The co-design process resulted in three clear sections within the questionnaire. Section 1 obtained general information about the farmer, their farm business, land and farming practices, including the crops grown and their current standard rotation(s). The purpose of this section was to build up a baseline understanding of the diversity of farms in our sample and enable appropriate interpretation of our main results. Section 2 assessed the current situation, specifically asking whether farmers had already begun to make changes to their practices, their flexibility of practice and the objectives and constraints in current cropping practice. We define objectives as goals that the farmer is aiming to achieve through their practices, for example 'financial independence' or 'control over a pest'. Constraints, on the other hand, are factors that limit the farmer's ability to practice as they wish, such as government regulation or biotic pressure. The questions of objectives and constraints were posed twice, once with respect to using rotations and once for individual crops, with the aim of determining whether farmers plan in terms of crops or rotations. Section 3 of the questionnaire sought to evaluate farmer responses to climate change.

Section 3 evolved considerably over the course of the co-design with the farmers. Initially we presented climate change as a 'climate change scenario', as used by scientists, which described future increases in $\mathrm{CO}_{2}$, durations of change and the frequencies and variances of extreme weather events. Over a series of discussions and reflections it became clear that this form of academic language was not useful to farmers: they focus on shorter-term forecasts of weather, rather than probabilistic projections of climate. Based on this feedback we then described a climate change scenario but from two viewpoints: a positive and negative viewpoint (Table 1). The positive viewpoint focused on opportunities, such as an earlier last-frost dates, while the negative viewpoint focused on impacts that could reduce opportunities for farmers such as water deficits during summer or elevated probabilities of pest attack (European Environment Agency, 2019). Each farmer was presented with both viewpoints in the same discussion and asked whether (and how) they would change their arable rotations in response to each. Comparing the responses to these two different viewpoints allowed us to determine how sensitive the farmers were to the presentations of climate change impacts. In the final part of section 3 , farmers were asked to self-assess as being optimistic or pessimistic regarding their experience of climate change, the questionnaire, and the information we gave them.

\subsection{Delivery of questionnaire}

We selected 4 distinct regions (three in France and one in the UK) that formed a latitudinal gradient (Fig. 1). The current impacts of climate change were expected to be more negative and more severe further south along the gradient (European Environment Agency, 2019). The questionnaire was translated from French to English, with minor changes to adapt it for the UK farming situation (both versions are available as Supplementary Material).

The semi-structured interviews were held in three regions across France during 2018. In the Occitanie in the southwest, the 13 farmers were contacted via an existing network managed by Solagro (a non-governmental organization working on food, agroecological and energy transitions). In the Bourgogne-Franche-Comté in the central-east, the 22 farmers were recruited via an established network on the Zone Atelier de Fenay and personal contact from the network. In the Hauts-de-France in the north, a network of 12 farmers were contacted though an acknowledged farmer contact. In the UK, the semi-structured interviews were held during 2019. A total of 28 farmers were invited via a network of existing contacts from the UK Centre for Ecology \& Hydrology, through word-ofmouth and by advertising the study in a blog post on the Agricology website. The farms were all located in the south of the UK: two in South Wales and 26 in southern England.

Interviews were carried out by Geoffroy Oudoire in France and by Miranda Bane in the UK. All farmers were provided with information about the research, opted in to give fully informed consent and were able to opt out at any stage in the process. AgroParisTech granted ethics approval to carry out this research.

We acknowledge that our sample of farmers was not necessarily representative because they were self-selecting as being willing to engage in research and discuss their agricultural practices and views on climate change. Many farmers belonged to the same agricultural network within each region and would have shared similar geographical and meteorological conditions. However, this should not negatively impact the relevance of the study because we did not aim to survey a random group of farmers but rather to gain a detailed insight from a sample of farmers in each region willing to discuss their views in depth. This approach enabled us to gain an understanding of the range of factors influencing farmer decision-making.

\subsection{Interpretation and analysis}

Open discussion questions in the questionnaire were summarized in writing during the interview and later codified to enable comparative analysis across the 4 regions. Coding is a way of undertaking content analysis by categorizing meanings from narrative (Young et al. 2017) by capturing the key points and the diversity of responses. For example, when asked to openly discuss crop rotation objectives, references to making more money for the farm were codified under the code 'Maximize income/profit'. Coding took place after all the interviews were complete and comprised initial, unsupervised coding followed by focused coding to standardize the categories and ensure that they were harmonized between the English and French interviews (Young et al., 2018). Coding was carried out by the authors with discussion to ensure consistency. Other parts of the questionnaire asked farmers to rate or select options from a list produced in the co-design; these responses could be analyzed without the need for coding. To aid our interpretation of the results, we discussed these results with farmers from Occitanie and Bourgogne-Franche-Comté during continued engagement with them by our organizations. We present summary figures of our main findings, providing detail and discussion based on the content of the interviews and subsequent engagement with farmers. 


\section{Results and discussion}

We present data from a total of 75 farmer interviews. The farms were either arable only (61\%) or a combination of arable crops and livestock (39\%). All farmers used arable rotations. Across all regions, $>70 \%$ of farmers stated that they 'use rotations to achieve particular objectives' ( $\mathrm{UK}=100 \%, \mathrm{HdF}=82 \%$, Bgn $=73 \%$, Oct $=92 \%$ ). The objectives identified in open discussion were broadly similar across the four regions, with weed control, maximizing profit/income, optimizing crop distribution, and improving the soil quality being most commonly raised. From the interviews it was clear that the farmers in our study balance the environmental (crop diversity, weeds, and soil) and economic (income and profit) sustainability of the farm in their planning. No single factor drives their planning alone. Only a small proportion of farmers raised 'responding to climate and weather' as an objective in open discussion, and only in the UK and Occitanie (both $<20 \%$ ). This suggests that responding to climate change is not an imperative at the forefront of planning for farmers, regardless of any potential climate impacts in their region. The other factors, in combination, appear to be more pressing.

\subsection{Is planning driven by objectives or constraints, and does this depend on whether farmers think in terms of crops or rotation?}

When asked to respond to a set of objectives and constraints generated during co-design, we found that all farmers more frequently rated objectives as important, compared to constraints (Figs. 2 and 3). This was true both for planning rotations and for planning which crops to grow. The objectives considered most important by the majority of farmers were securing/diversifying income and improving the soil quality. These results align with the objectives raised by farmers in open discussion about whether they use rotations to achieve particular objectives. This would suggest that finance and a healthy arable environment are key to farmers planning, irrespective of the region (and associated variables) concerned. In discussion, many farmers described a balancing act between finance and improving the arable environment, wanting to achieve positive outcomes for both objectives despite them not always being aligned. Finance plays a role in the adoption of practices that benefit the arable environment, for example there are financial constraints on reducing pesticide use (Chèze et al., 2020). For those farmers with livestock (39\%), livestock feed autonomy was considered particularly important. This highlights that arable farming done in combination with livestock farming, can lead to a different hierarchy of priorities. Reduction of working time and equipment independence were least likely to be considered to be important in all regions. The farmers we interviewed were self-selected, and within the different regions some were connected by family, social and/or commercial ties, as well as sharing agroecological contexts. Thus, the sample can be criticized as not being representative of all farmers doing arable agriculture. Nonetheless, we note that our findings align with other studies such as Chongtham et al. (2017) which support soil quality and weed

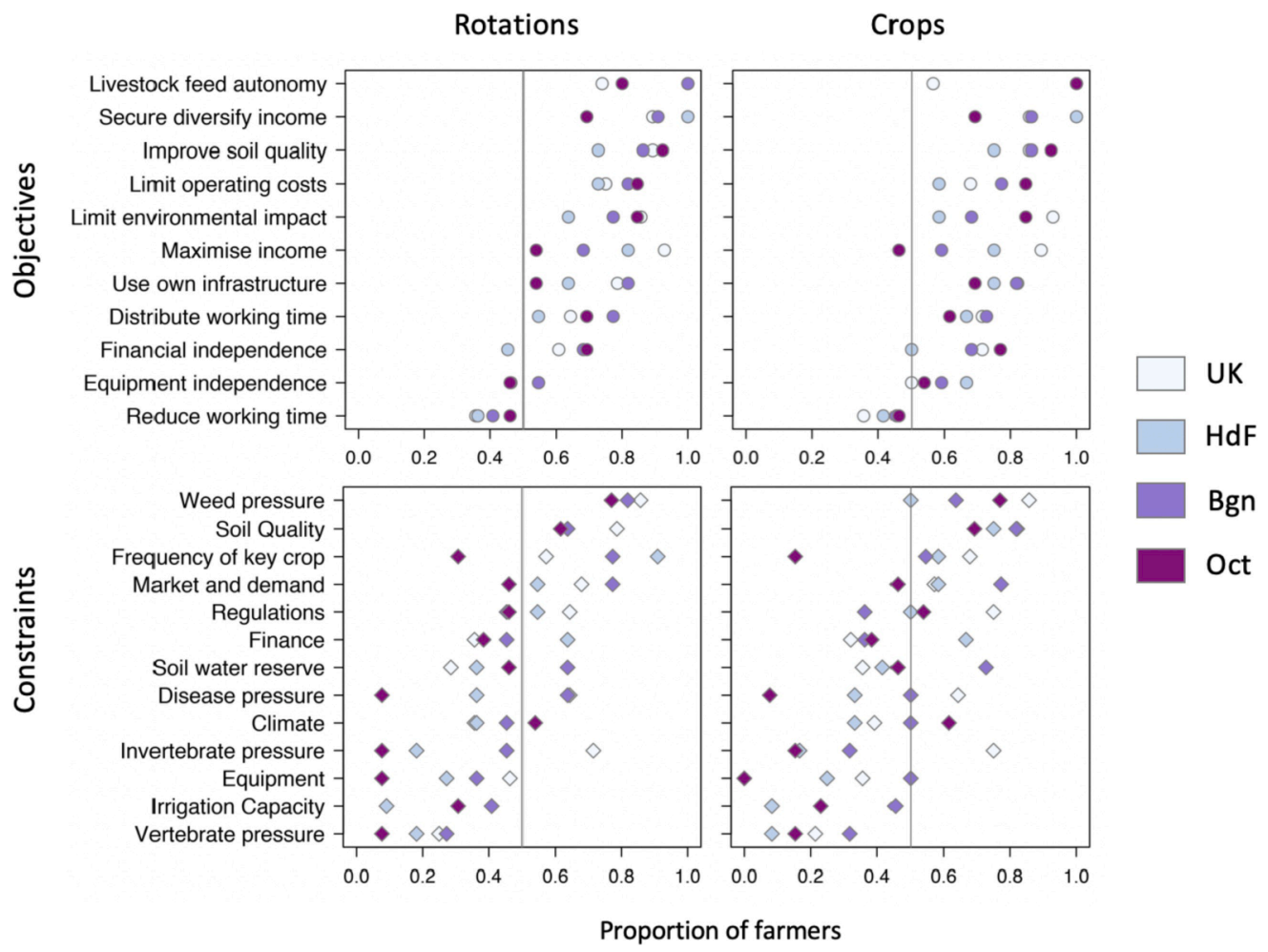

Fig. 2. The proportion of farmers that agreed each Objective (top panel) or Constraint (bottom panel) was considered when planning their Rotations (left) and Crops (right). Farmers are grouped by region (see key). There were no substantial differences between regions. The vertical line at 0.5 is added for reference. 

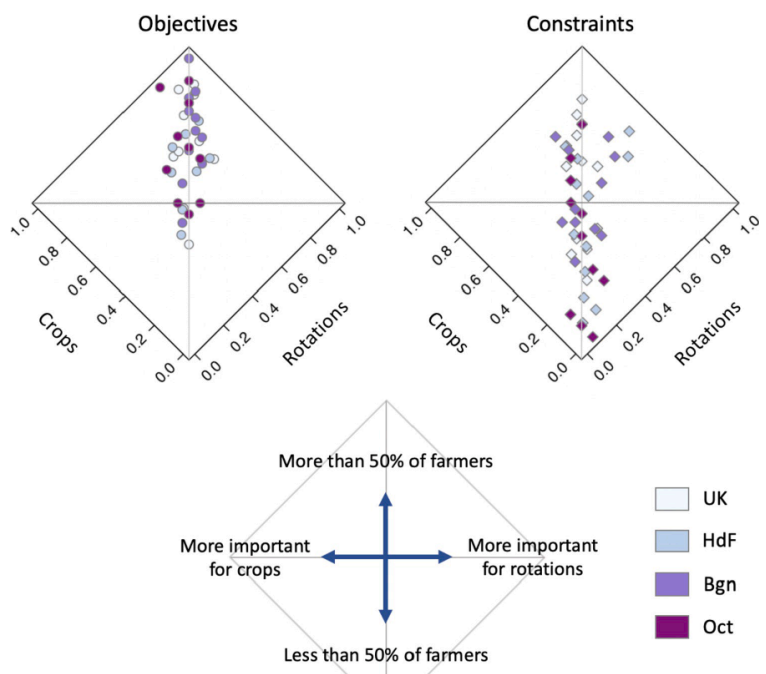

Fig. 3. Overview of proportions of farmers from Fig. 2. For both plots, refer to key plot below: points that sit above the horizontal line indicate that more than half of the farmers questioned considered the objective (left) or constraint (right) in question to be important in their planning. Points that sit exactly on the vertical line in each plot indicate that the objective or constraint in question was considered the same in the context of crops and rotations. Variation from the vertical indicates the objective or constraint was considered to have different importance to crops vs rotation.

a) Flexibility:

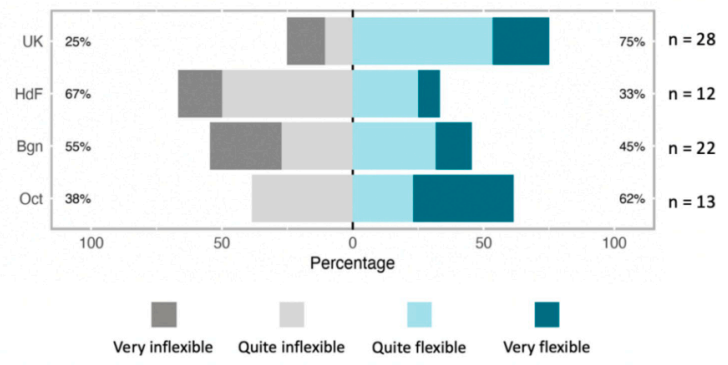

b) Means of Flexibility:

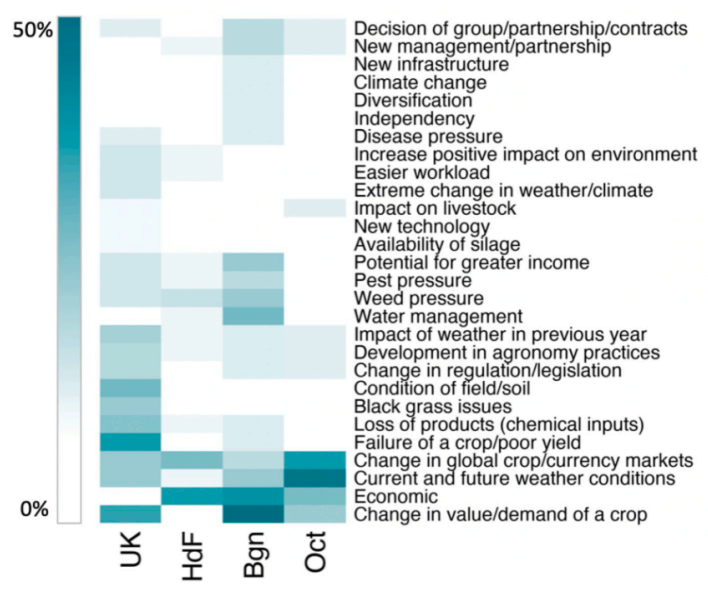

Fig. 4. The flexibility (a) and means of flexibility (b) of farmers. a) Likert plot showing how farmers in each region that responded when asked how flexible they are in their planning. The percentage of farmers is normalized for each region by the number of farmers (n). b) Factors driving flexibility, as raised in discussion by the farmers in each region. The color scale indicates the percentage of farmers from each region that raised each factor. Twenty-eight distinct factors were codified from open discussion. 
control being important in decision making, feed production being critical for farmers with livestock, and weed pressures and financial/market forces having the greatest influence on practices. We also note that farmers from across all four regions, having no shared ties, showed similar responses suggesting that there is a generic conception of arable farming objectives and their relative importance (Figs. 2 and 3). This may be due to consensus on core farming practices in this part of Europe.

The similarity of responses for crops and rotations (Fig. 3), and discussion with farmers around this, showed that crop choice is integrated with planning rotations, rather than independent from it. In several cases, farmers stated that crops and rotations were inseparable and scored them identically. So, while individual crops contribute to the achievement of farming objectives, they do this as part of coherent crop rotations, supporting our prior expectation. This shows the importance of taking a rotation-based approach in research and agronomic planning for the future.

\subsection{Are farmers flexible in their planning and what drives flexibility?}

The majority of famers in the UK (75\%) considered themselves to be quite or very flexible in their planning. This figure is lower in France (33-62\%) but increases from north to south (Fig. 4a). This may be due to differences between the two countries in past national planning, regulations, and economic decision making for agriculture. France has a strong tradition of national planning, e.g. production of sugar beet in the Hauts-de-France and use of a standard 'wheat - oilseed rape - barley' rotation in Bourgogne-FrancheComté (agreste HAUTS-DE-FRANCE, 2020; Boizard et al., 2012; Meynard et al., 2018). It is possible that greater exposure to climate impacts to date in the south (Ceglar et al., 2019) elicits flexibility out of necessity.

The factors that drive flexibility differed quite substantially for the farmers in the four regions although the key factors were those linked to economic opportunities and market demand (Fig. 4b), confirming the previously found importance of finance in planning (Fig. 2). Current and future weather conditions were cited by several farmers, from all regions except the Haut-de-France, as driving the need for flexibility. We have no clear explanation for this difference in the Haut-de-France. It might result from a combination of past and current exposure to climate change; regional, geographical and meteorological factors (e.g. topology); and governmental regulation for the local types of crops grown. In this region, rotations are structured around sugar beet with past economic decisionmaking and government support for this pattern of cropping (agreste HAUTS-DE-FRANCE 2020; Meynard et al. 2018). Such regulation of cropping, via governmental support, may affect farmer flexibility due to their perception of the control over the choice of crops that they have (Doran et al. 2020).

\subsection{Have farmers been impacted by climate change?}

Farmers overwhelmingly agreed that they have experienced the impacts of climate change during their lifetime. Only in the UK did a small proportion of farmers (21\%) say that they had not experienced impacts of climate change (Fig. 5). These results are in keeping with our expectation that in more northern latitudes farmers are less likely to have direct personal experience of climate change.

The majority of farmers (up to $83 \%$ in the Hauts-de-France region) said that experience of climate change had led them to make changes to their farming practices (Fig. 5), although the proportion was lowest in both the northern and southern-most regions. These results strongly confirm that climate change has already had an impact on arable farming practices, and that farmers are actively
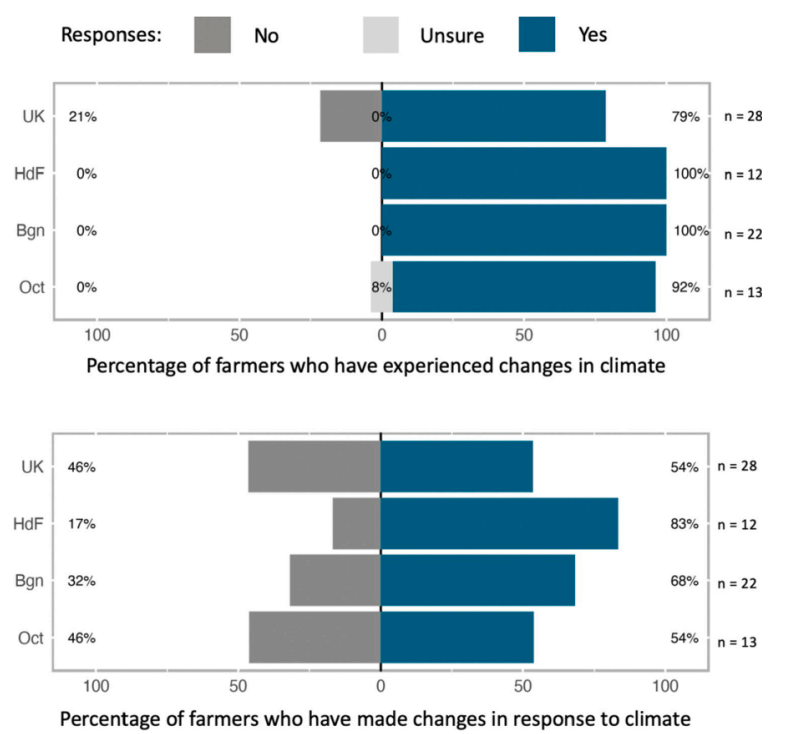

Fig. 5. The proportion of farmers from each region who said they had experienced changes in the climate during their working lifetime (top) compared to the proportion of farmers who said they had made a change(s) to their practices in response to, or in order to mitigate, these changes (bottom). 
responding to this issue, although more farmers say they have experienced the impacts, than have responded by adapting to the impacts of climate change. This may be linked to a number of potential explanations found elsewhere in the questionnaire, including: i) some farmers being inflexible in their planning (Fig. 4); ii) that many other objectives and constraints play a role in planning (Fig. 2); and, as discussed below, iii) variation in the outlook of the farmers. Our post-interview discussions with the co-design group of farmers on the interpretation of these results also suggested that climate change might have already impacted the southern end of the gradient for a considerable period of time, so farmers there are habituated to the changing climate and now integrate it as part of their normal experience of variation in weather. This aligns with Wheeler et al. (2021) who found that farmers accepted climate change over time as a new normal, which impacted their response to it.

\subsection{How do farmers respond to positive and negative viewpoints of climate change?}

We discovered from the initial co-design of the questionnaire that farmers responded best when climate change impacts were presented as narrative viewpoints, rather than as academic projections. We found that across all regions, farmers were more likely to diversity or lengthen rotations than shorten them in response to the climate change scenarios, irrespective of the viewpoint (Fig. 6). Crucially however, we found consistent differences in the responses of each farmer to the positive and negative viewpoint; farmers were more likely to adapt by proposing longer or more diverse rotations in response to positive viewpoints. The majority of farmers would diversify (mean across regions $=79 \%$ ) and lengthen $(67 \%)$ rotations when presented with a positive viewpoint of climate change, whereas only half (diversify $=53 \%$; lengthen $=49 \%$ ) would do so when presented with a negative viewpoint. Similarly, few farmers (mean across regions $=4 \%$ ) would shorten rotations when presented with the positive viewpoint, but more (20\%) would shorten them when presented with the negative viewpoint of climate change. Clearly the communication of the impacts of climate change is important (Spence and Pidgeon, 2010), as shown here in the way in which farmer predict that they will respond to climate change.

The language around climate change is often framed negatively (Sorvali, Kaseva and Peltonen-Sainio, 2021) and our co-design group of farmers stated that it was often received in this way. Our results confirm that the framing of the impacts of climate change in communications affects the receiver's response (Morton et al., 2011). In our study, presenting both positive and negative viewpoints helped farmers to consider the future opportunities as well as constraints. This approach appears to have elicited greater flexibility and adaptation in their conception of future rotations, which aligns with other environmental benefits for ecosystem services from arable diversification that are supported, for example by the European Union (European Environment Agency, 2019). From open discussion, farmers viewed diversifying and lengthening rotations as positive and desirable due to the associated benefits to the soil and the potential for diversified income. Longer and more diverse rotations are a feature of organic agriculture, for these reasons
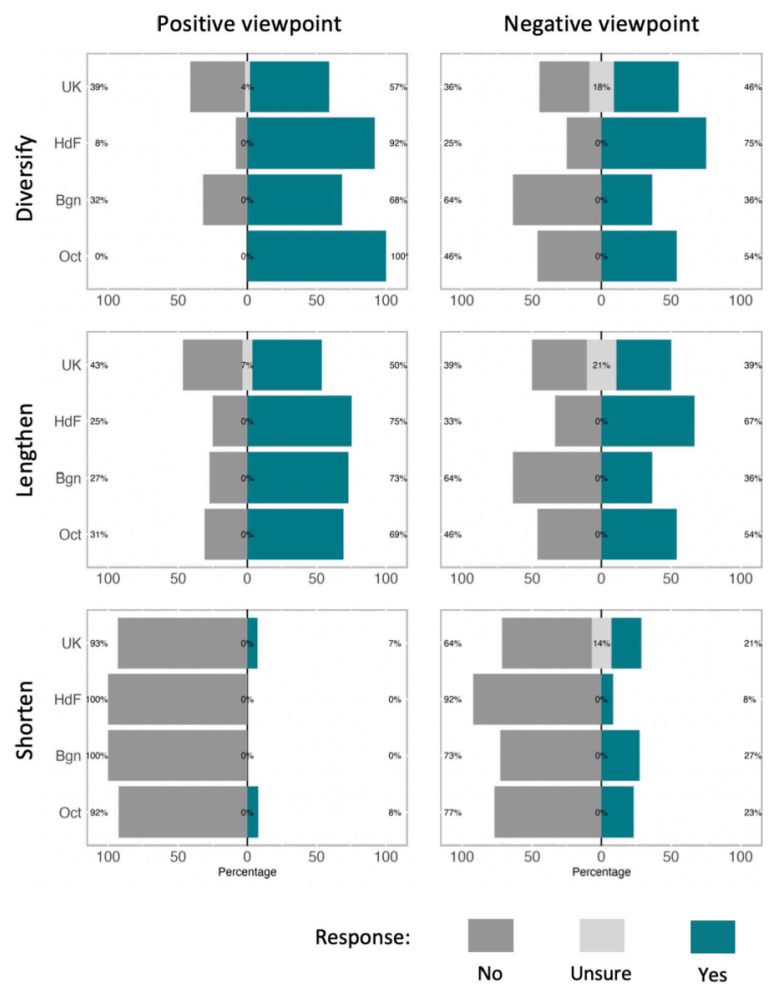

Fig. 6. The responses of farmers in the 4 regions to the two climate projections (positive and negative) in terms of whether they would diversify, lengthen, or shorten their rotations. 
(Barbieri et al., 2017). From a research perspective, longer and more diverse rotations are two strategies to adapt to and mitigate climate change, by improving the health of the arable environment and increasing biodiversity (Tiemann et al., 2015). This is supported by the European Union in reforms of the Common Agricultural Policy (European Environment Agency, 2019). Conversely, farmers were consistently more likely to respond to a negative climate scenario with shorter and less diverse rotations, despite them acknowledging that these were less good for the environment and income opportunities. This could be due to risk aversion. Despite consistently opposing responses to the positive and negative viewpoints, many farmers explicitly stated both that the climate projections did not give enough detail for them to make precise predictions of their responses to climate change, and that there were many other factors, such as economics, which would have to be considered in each region. Future research should explicitly address these issues to understand the complexity of motivations and factors that play a role in responses to differently framed scenarios.

The farmer responses to the two climate change viewpoints (positive and negative) individually were more limited than the responses to both together. This has important implications for future agricultural planning because presenting multiple, evidence-based projections of impacts appears to allow consideration of a wider range of responses and, potentially greater flexibility when undertaking planning. This also appears to be a benefit of using narrative viewpoints rather than single, probabilistic academic scenarios of climate change, which the co-design farmers stated could not be easily translated into their practice and were typically interpreted as constraints. The co-design process of the questionnaire and our results led us to conclude that communicating the impact of climate change needs to be framed in a context that is more applicable to (operational for) farmers. Climate change scenarios used for communication should have clear examples of impacts on local weather events, pests and diseases through agro-climatic indicators (e. g. the number of days higher than $25^{\circ} \mathrm{C}$ in June and July for wheat). Adopting language, framing and indicators that are farmerorientated could help to highlight the vulnerability of the farm and the farming practices whilst providing conceptual tools to innovate new rotational practice.

\subsection{Are farmers generally optimistic or pessimistic about future climate impacts on agriculture?}

Farmer outlook, based on experience and awareness of climate change and the climate viewpoints presented in the questionnaire, varied across the regions with a clear trend from greatest optimism in the UK and greatest pessimism in the south of France (Fig. 7). This trend fits with our expectation that those farmers facing imminent, and perhaps more extreme, climate change would be more pessimistic, while benefits from longer growing periods and novel crops will be experienced more towards the north of Europe (European Environment Agency, 2019). Given that farmers towards the south of the transect had a higher likelihood of having experienced climate change (Ceglar et al., 2019) our results suggests that current exposure to climate change impacts was more likely to lead to a pessimistic outlook about the future. People view climate change based on their lived experience (Akter et al., 2012; O'Connor et al., 1999), so our results could also indicate that there is higher 'risk skepticism' in the north, because farmers reduced experience of climate change leads to greater confidence that any risks can be dealt with (Islam et al., 2013). Additional considerations such a regional attitudes, tradition and politics may also play a role in pessimism; nearly all UK farmers suggested uncertainty around the UK leaving the European Union impacted their outlook.

\section{Conclusion}

This work contributes to the overall aim of bridging the communication gap between researchers and farmers in order to better work with farmers and represent farmers' opinions in climate research. By working directly with farmers, we identified several characteristics that should influence communication of researchers and decision-makers with farmers.

The arable farmers we spoke to made it clear that they think and plan in terms of rotations. This is important for communication with farmers because most agricultural climate change research has considered climate change in terms of impacts on individual crops, and adaptation through breeding, crop varieties and intercropping. The rotational system is primarily driven by positive objectives, especially financial opportunities and soil health, but is also determined by constraints. Future research and interventions from policy makers should explicitly consider arable farming as rotations, not individual crops, to better meet the needs of farmers.

We found that the way in which climate change is presented affects farmer decision-making and hence could have multiple benefits for economic resilience, environmental sustainability, and ecosystem services. In the face of contrasted climate projections, farmers across all regions respond similarly to a perspective that highlighted future opportunities; they proposed that they were likely to diversify or lengthen their rotations. In contrast, the negative viewpoint of climate change led to a restricted perception and a higher uptake of shorter rotations across all regions. A more diverse and well-informed range of farmers responses, developed through communicating diverse narratives around climate change impacts, may safeguard their business and help to mitigate climate impacts in the future.

We also found that the context and attitude of the farmers matters, even within western Europe. It was notable that even from south of France (suffering negative effects of climate change) to southern England (gaining some benefits e.g. from new crops being grown) there was little evidence that current rotational practices and planning are affected by the latitudinal gradient; possibly as a result of Common Agricultural Policy within the European Union and because farmers are working towards broadly similar goals of economic sustainability. This finding is encouraging for policymaking and research because it suggests that there a broadly common basis for developing interventions and incentives in this type of arable farming. Nonetheless, nearly all farmers in our study believed they had personal experience of climate change and have made changes to their practices as a consequence. However, our results show that farmers became progressively more pessimistic towards the south of our latitudinal gradient. So, we found no evidence of a latitudinal gradient on current practice and flexibility, but there was a trend based on farmer experience and their outlook on climate change 


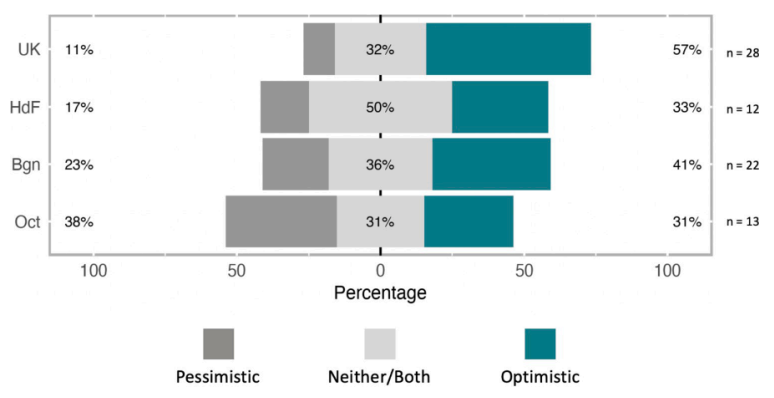

Fig. 7. The proportion of farmers in each region who identified as being 'Pessimistic', 'Optimistic, 'Neither' or 'Both' (combined) in their outlook on climate change, based on the experience and awareness, and having just discussed the climate viewpoints in the questionnaire.

impacts. This decoupling of experience/outlook and current practice validates the use of latitude as a variable for studying climate change impacts on the attitudes of farmers. Our findings suggest a disconnect between farmer sentiment and farming practice to date. Our findings suggest that farmers with either optimistic or pessimistic outlooks might be differentially disposed to adopting rotational change in response to their perception of future climate. This should be explored further as understanding how a positive or negative mindset impacts farmer decision-making could contribute to the development of agricultural policy and regulation.

Arable farming is a complex process built upon many diverse objectives and constraints, and climate change is an additional factor. Diversified rotational farming practices have proven agronomic and environmental impacts. Including farmer knowledge, experience and sentiment towards climate change will be vital for progress in developing future rotational management practice. We propose there is an opportunity for farmer adaptation to climate change to be aligned with incentives and interventions at the policy level eliciting beneficial outcomes for farmers and the environment. Ultimately, communicating in a way that is clear and useful to both researchers and farmers is vital for this alignment to be realized.

\section{Declaration of Competing Interest}

The authors declare that they have no known competing financial interests or personal relationships that could have appeared to influence the work reported in this paper.

\section{Acknowledgements}

MB and MP were funded by the UK Department for Environment, Food and Rural Affairs (contract SCF0313). DB and SD were funded by the Agence National de la Recherche (ANR). This work is an output of the PREAR project (Predicting and enhancing the Resilience of European Agro-ecosystems to environmental change using crop Rotations) which was a partnership between INRAE, UKCEH, Universities of Copenhagen and Aarhus, Solagro and Szent István University. It was funded as part of the European FACCE SURPLUS (sustainable and resilient agriculture for food and non-food systems) ERA-NET co-fund scheme of Horizon 2020 program formed in collaboration between the European Commission and a partnership of 15 countries in the frame of the Joint Programming Initiative on Agriculture, Food Security and Climate Change (FACCE-JPI). We thank the farmers who participated in this study, both those of the co-construction group and those responding to the questionnaire. For facilitating contact with farmers, we are indebted to Guillaume Brisset in the Hauts-de-France, and Jodey Peyton and Richard Pywell in the UK. We thank the GAEC MOUILLON FRERES LAURENT ET OLIVIER and Pauline Mouillon in the Bourgogne-Franche-Comte for their support and discussions throughout the questionnaire co-construction and interpretation process.“

\section{References}

agreste HAUTS-DE-FRANCE, 2020. Des marges de progrès vers plus d'agro-écologie dans l'utilisation des produits phytopharmaceutiques en grandes cultures. Septembre $2020 \mathrm{~N}^{\circ}$ 2. Available at https://draaf.hauts-de-france.agriculture.gouv.fr/IMG/pdf/Dossier2-phytosanitaire-corrige_cle4e3cd8.pdf Accessed 19 Aug 2021.

Akter, S., Bennett, J., Ward, M.B., 2012. Climate change scepticism and public support for mitigation: Evidence from an Australian choice experiment. Glob. Environ. Change 22, 736-745. https://doi.org/10.1016/j.gloenvcha.2012.05.004.

Arbuckle Jr., J.G., Morton, L.W., Hobbs, J., 2015. Understanding farmer perspectives on climate change adaptation and mitigation: The roles of trust in sources of climate information, climate change beliefs, and perceived risk. Environ. Behav. 47 (2), 205-234. https://doi.org/10.1177/0013916513503832.

Barbieri, P., Pellerin, S., Nesme, T., 2017. Comparing crop rotations between organic and conventional farming. Sci. Rep. 7, 13761. https://doi.org/10.1038/s41598017-14271-6.

Ball, B.C., Bingham, I., Rees, R.M., Watson, C.A., Litterick, A., 2005. The role of crop rotations in determining soil structure and crop growth conditions. Can. J. Soil Sci. 85, 557-577. https://doi.org/10.4141/S04-078.

Behnke, G.D., Zuber, S.M., Pittelkow, C.M., Nafziger, E.D., Villamil, M.B., 2018. Long-term crop rotation and tillage effects on soil greenhouse gas emissions and crop production in Illinois, USA. Agric. Ecosyst. Environ. 261, 62-70. https://doi.org/10.1016/j.agee.2018.03.007.

Boizard, H., Duval, R., Lemaitre, T., Machet, J.M., Mary, B., Beaudoin, N., Cariolle, M., Escriou, H., Gosse, G., Richard-Molard, M., Boiffin, J., 2012. Sugar beet, a sustainability factor of arable crop systems in northern France. Labour 313 (296), 311.

Bullock, D.G., 1992. Crop rotation. Crit. Rev. Plant Sci. 11, 309-326. https://doi.org/10.1080/07352689209382349.

Castellazzi, M.S., Wood, G.A., Burgess, P.J., Morris, J., Conrad, K.F., Perry, J.N., 2008. A systematic representation of crop rotations. Agric. Syst. 97, 26-33. https:// doi.org/10.1016/j.agsy.2007.10.006. 
Ceglar, A., Zampieri, M., Toreti, A., Dentener, F., 2019. Observed Northward Migration of Agro-Climate Zones in Europe Will Further Accelerate Under Climate Change. Earths Future 7, 1088-1101. https://doi.org/10.1029/2019EF001178.

Chèze, B., David, M., Martinet, V., 2020. Understanding farmers' reluctance to reduce pesticide use: a choice experiment. Ecol. Econ. 167, 106349 https://doi.org/ 10.1016/j.ecolecon.2019.06.004.

Chongtham, I.R., Bergkvist, G., Watson, C.A., Sandström, E., Bengtsson, J., Öborn, I., 2017. Factors influencing crop rotation strategies on organic farms with different time periods since conversion to organic production. Biol. Agric. Hortic. 33, 14-27. https://doi.org/10.1080/01448765.2016.1174884.

Degani, E., Leigh, S.G., Barber, H.M., Jones, H.E., Lukac, M., Sutton, P., Potts, S.G., 2019. Crop rotations in a climate change scenario: short-term effects of crop diversity on resilience and ecosystem service provision under drought. Agric. Ecosyst. Environ. 285, 106625 https://doi.org/10.1016/j.agee.2019.106625.

Doran, E.M., Zia, A., Hurley, S.E., Tsai, Y., Koliba, C., Adair, C., Schattman, R.E., Rizzo, D.M., Méndez, V.E., 2020. Social-psychological determinants of farmer intention to adopt nutrient best management practices: implications for resilient adaptation to climate change. J. Environ. Manage. 276, 111304 https://doi.org/ 10.1016/j.jenvman.2020.111304.

Dury, J., Schaller, N., Garcia, F., Reynaud, A., Bergez, J.E., 2012. Models to support cropping plan and crop rotation decisions. A review. Agron. Sustain. Dev. 32, 567-580. https://doi.org/10.1007/s13593-011-0037-x.

Eitzinger, A., Binder, C.R., Meyer, M.A., 2018. Risk perception and decision-making: do farmers consider risks from climate change? Clim. Change 151 (3), 507-524. https://doi.org/10.1007/s10584-018-2320-1.

European Environment Agency, 2019. Climate change adaptation in the agriculture sector in Europe.

Feola, G., Binder, C.R., 2010. Towards an improved understanding of farmers' behaviour: The integrative agent-centred (IAC) framework. Ecol. Econ. 69, $2323-2333$. https://doi.org/10.1016/j.ecolecon.2010.07.023.

Feola, G., Lerner, A.M., Jain, M., Montefrio, M.J.F., Nicholas, K.A., 2015. Researching farmer behaviour in climate change adaptation and sustainable agriculture: Lessons learned from five case studies. J. Rural Stud. 39, 74-84. https://doi.org/10.1016/j.jrurstud.2015.03.009.

Gan, Y., Liang, C., Chai, Q., Lemke, R.L., Campbell, C.A., Zentner, R.P., 2014. Improving farming practices reduces the carbon footprint of spring wheat production. Nat. Commun. 5, 5012. https://doi.org/10.1038/ncomms6012.

Geiger, F., Bengtsson, J., Berendse, F., Weisser, W.W., Emmerson, M., Morales, M.B., Ceryngier, P., Liira, J., Tscharntke, T., Winqvist, C., Eggers, S., Bommarco, R., Pärt, T., Bretagnolle, V., Plantegenest, M., Clement, L.W., Dennis, C., Palmer, C., Oñate, J.J., Guerrero, I., Hawro, V., Aavik, T., Thies, C., Flohre, A., Hänke, S., Fischer, C., Goedhart, P.W., Inchausti, P., 2010. Persistent negative effects of pesticides on biodiversity and biological control potential on European farmland. Basic Appl. Ecol. 11, 97-105. https://doi.org/10.1016/j.baae.2009.12.001.

Haden, V.R., Niles, M.T., Lubell, M., Perlman, J., Jackson, L.E., 2012. Global and Local Concerns: What Attitudes and Beliefs Motivate Farmers to Mitigate and Adapt to Climate Change? PLoS ONE 7, e52882. https://doi.org/10.1371/journal.pone.0052882.

IPCC, 2018. Summary for Policymakers. In: Global Warming of $1.5^{\circ} \mathrm{C}$. An IPCC Special Report on the impacts of global warming of $1.5^{\circ} \mathrm{C}$ above pre-industrial levels and related global greenhouse gas emission pathways, in the context of strengthening the global response to the threat of climate change, sustainable development, and efforts to eradicate poverty.

Islam, Md.M., Barnes, A., Toma, L., 2013. An investigation into climate change scepticism among farmers. J. Environ. Psychol. 34, 137-150. https://doi.org/10.1016/ j.jenvp.2013.02.002.

Leng, G., Huang, M., 2017. Crop yield response to climate change varies with crop spatial distribution pattern. Sci. Rep. 7, 1463. https://doi.org/10.1038/s41598017-01599-2.

Lesk, C., Rowhani, P., Ramankutty, N., 2016. Influence of extreme weather disasters on global crop production. Nature 529, 84-87. https://doi.org/10.1038/ nature16467.

Meynard, J.M., Charrier, F., Le Bail, M., Magrini, M.B., Charlier, A., Messéan, A., 2018. Socio-technical lock-in hinders crop diversification in France. Agron. Sustainable Dev. 38 (5), 1-13. https://doi.org/10.1007/s13593-018-0535-1.

Mitter, H., Larcher, M., Schönhart, M., Stöttinger, M., Schmid, E., 2019. Exploring farmers' climate change perceptions and adaptation intentions: Empirical evidence from Austria. Environ. Manage. 63 (6), 804-821. https://doi.org/10.1007/s00267-019-01158-7.

Morton, T.A., Rabinovich, A., Marshall, D., Bretschneider, P., 2011. The future that may (or may not) come: How framing changes responses to uncertainty in climate change communications. Glob. Environ. Change 21, 103-109. https://doi.org/10.1016/j.gloenvcha.2010.09.013.

Mulder, C., Sechi, V., Woodward, G., Bohan, D.A., 2017. Ecological Networks in Managed Ecosystems: Connecting Structure to Services, in: Moore, J.C., de Ruiter, P. C., McCann, K.S., Wolters, V. (Eds.), Adaptive Food Webs. Cambridge University Press, pp. 214-227. doi: 10.1017/9781316871867.016.

Nguyen, T.P.L., Seddaiu, G., Virdis, S.G.P., Tidore, C., Pasqui, M., Roggero, P.P., 2016. Perceiving to learn or learning to perceive? Understanding farmers' perceptions and adaptation to climate uncertainties. Agric. Syst. 143, 205-216. https://doi.org/10.1016/j.agsy.2016.01.001.

O'Cathain, A., Thomas, K.J., 2004. “Any other comments?” Open questions on questionnaires-a bane or a bonus to research? BMC Med. Res. Method 4 (1), 1-7. https://doi.org/10.1186/1471-2288-4-25.

O'Connor, R.E., Bard, R.J., Fisher, A., 1999. Risk perceptions, general environmental beliefs, and willingness to address climate change. Risk Anal. 19, 461-471. https://doi.org/10.1111/j.1539-6924.1999.tb00421.x.

Olesen, J.E., Bindi, M., 2002. Consequences of climate change for European agricultural productivity, land use and policy. Eur. J. Agron. 16, 239-262. https://doi. org/10.1016/S1161-0301(02)00004-7.

Pankhurst, C.E., Lynch, J.M., 2005. Biocontrol of soil-borne plant diseases, in: Encyclopedia of Soils in the Environment. Elsevier, pp. 129-136. 10.1016/B0-12348530-4/00137-5

Ray, D.K., West, P.C., Clark, M., Gerber, J.S., Prishchepov, A.V., Chatterjee, S., 2019. Climate change has likely already affected global food production. PLoS ONE 14, e0217148. https://doi.org/10.1371/journal.pone.0217148.

Schiere, J.B., Darnhofer, I., Duru, M., 2012. Dynamics in farming systems: of changes and choices, in: Darnhofer, I., Gibbon, D., Dedieu, B. (Eds.), Farming Systems Research into the 21st Century: The New Dynamic. Springer Netherlands, Dordrecht, pp. 337-363. 10.1007/978-94-007-4503-2_15.

Sindelar, A.J., Schmer, M.R., Jin, V.L., Wienhold, B.J., Varvel, G.E., 2016. Crop rotation affects corn, grain sorghum, and soybean yields and nitrogen recovery. Agron. J. 108, 1592-1602. https://doi.org/10.2134/agronj2016.01.0005.

Sloat, L.L., Davis, S.J., Gerber, J.S., Moore, F.C., Ray, D.K., West, P.C., Mueller, N.D., 2020. Climate adaptation by crop migration. Nat. Commun. 11, 1243. https:// doi.org/10.1038/s41467-020-15076-4.

Spence, A., Pidgeon, N., 2010. Framing and communicating climate change: the effects of distance and outcome frame manipulations. Glob. Environ. Change 20, 656-667. https://doi.org/10.1016/j.gloenvcha.2010.07.002.

Sorvali, J., Kaseva, J., Peltonen-Sainio, P., 2021. Farmer views on climate change-a longitudinal study of threats, opportunities and action. Clim. Change 164 (3), 1-19. https://doi.org/10.1007/s10584-021-03020-4.

Storkey, J., Bruce, T.J.A., McMillan, V.E., Neve, P., 2019. The Future of Sustainable Crop Protection Relies on Increased Diversity of Cropping Systems and Landscapes, in: Agroecosystem Diversity. Elsevier, pp. 199-209. 10.1016/B978-0-12-811050-8.00012-1.

Teixeira, E.I., de Ruiter, J., Ausseil, A.-G., Daigneault, A., Johnstone, P., Holmes, A., Tait, A., Ewert, F., 2018. Adapting crop rotations to climate change in regional impact modelling assessments. Sci. Total Environ. 616-617, 785-795. https://doi.org/10.1016/j.scitotenv.2017.10.247.

Therond, O., Duru, M., Roger-Estrade, J., Richard, G., 2017. A new analytical framework of farming system and agriculture model diversities. A review. Agron. Sustain. Dev. 37, 21. https://doi.org/10.1007/s13593-017-0429-7.

Tiemann, L.K., Grandy, A.S., Atkinson, E.E., Marin-Spiotta, E., McDaniel, M.D., 2015. Crop rotational diversity enhances belowground communities and functions in an agroecosystem. Ecol. Lett. 18, 761-771. https://doi.org/10.1111/ele.12453.

Vasileiadis, V.P., Sattin, M., Otto, S., Veres, A., Pálinkás, Z., Ban, R., Pons, X., Kudsk, P., van der Weide, R., Czembor, E., Moonen, A.C., Kiss, J., 2011. Crop protection in European maize-based cropping systems: Current practices and recommendations for innovative Integrated Pest Management. Agric. Syst. 104, 533-540. https://doi.org/10.1016/j.agsy.2011.04.002. 
Vogel, E., Donat, M.G., Alexander, L.V., Meinshausen, M., Ray, D.K., Karoly, D., Meinshausen, N., Frieler, K., 2019. The effects of climate extremes on global agricultural yields. Environ. Res. Lett. 14, 054010 https://doi.org/10.1088/1748-9326/ab154b.

Weisberger, D., Nichols, V., Liebman, M., 2019. Does diversifying crop rotations suppress weeds? A meta-analysis. PLOS ONE 14, e0219847. https://doi.org/10.1371/ journal.pone.0219847.

Wheeler, S.A., Nauges, C., Zuo, A., 2021. How stable are Australian farmers' climate change risk perceptions? New evidence of the feedback loop between risk perceptions and behaviour. Global Environ. Change 68, 02274. https://doi.org/10.1016/j.gloenvcha.2021.102274.

Wolf. J, 2011. Climate Change Adaptation in Developed Nations: From Theory to Practice, Advances in Global Change Research. Springer Netherlands, Dordrecht. 10.1007/978-94-007-0567-8.

Young, J.C., Rose, D.C., Mumby, H.S., Benitez-Capistros, F., Derrick, C.J., Finch, T., Garcia, C., Home, C., Marwaha, E., Morgans, C., Parkinson, S., Shah, J., Wilson, K. A., Mukherjee, N., 2018. A methodological guide to using and reporting on interviews in conservation science research. Methods Ecol. Evol. 9, 10-19. https://doi. org/10.1111/2041-210X.12828. 